\title{
Seeking Gender Equality in the Tourism Sector: A Systematic Bibliometric Review
}

\author{
Noelia Araújo-Vila *(D), Almudena Otegui-Carles and Jose A. Fraiz-Brea $\mathbb{B}$
}

Business and Tourism Faculty, Universidade de Vigo, 32004 Ourense, Spain; almudena.otegui@uvigo.es (A.O.-C.); jafraiz@uvigo.es (J.A.F.-B.)

* Correspondence: naraujo@uvigo.es

Citation: Araújo-Vila, N.;

Otegui-Carles, A.; Fraiz-Brea, J.A.

Seeking Gender Equality in the

Tourism Sector: A Systematic

Bibliometric Review. Knowledge 2021,

1, 12-24. https://doi.org/10.3390/

knowledge1010003

Academic Editor: Jose María Merigo

Received: 22 July 2021

Accepted: 27 September 2021

Published: 29 September 2021

Publisher's Note: MDPI stays neutral with regard to jurisdictional claims in published maps and institutional affiliations.

Copyright: (c) 2021 by the authors. Licensee MDPI, Basel, Switzerland. This article is an open access article distributed under the terms and conditions of the Creative Commons Attribution (CC BY) license (https:// creativecommons.org/licenses/by/ $4.0 /)$.

\begin{abstract}
Sustainability in tourism cannot be achieved without decent work, gender equality and empowerment of all women. Most of the workforce in the tourism sector is women, and although this sector offers great opportunities for empowerment and gender equality, there are many inequalities that occur in it. To find solutions it is necessary to have a greater knowledge, and therefore it is necessary to analyze how the gender equality research is progressing. The objective of this paper is to analyse how the concept of gender equality in tourism is present in academic research. For this purpose, a systematic review of the existing scientific literature is carried out, based on a bibliometric review of the works on gender equality in the field of tourism published in the Scopus database. The analysis carried out shows that, although there has been a year-on-year increase in publications related to gender equality in the field of tourism, there are still few studies focused on this subjetc, and that only in the last time have they been linked to the family. The analysis also reveals that only a few journals and authors concentrate publications related to gender equality in tourism.
\end{abstract}

Keywords: academic research; agenda 2030; database; employment; equality; gender; tourism; scopus; women

\section{Introduction}

Despite progress over the years, many challenges remain to achieved a fundamental human right: Gender equality [1]. Without gender equality and empowerment of women, the achievement of progress and sustainable development is not possible, because rights and opportunities would be denied to half of humanity [1]. That is precisely why it is one of the Sustainable Development Goals (SDGs) on the 2030 Agenda: Goal 5. Achieve gender equality and empower all women and girls [1]. Gender equality must also be considered in the achievement of other goals and, especially, in Goal 8: Promote sustained, inclusive, and sustainable economic growth, full and productive employment and decent work for all [1]. Tourism has an important role in achieving the commitments of the 2030 Agenda, since tourism has been widely accepted as an essential tool to promote gender equality [2], but many changes are still needed to achieve that equality in the tourism sector. Sustainability in tourism cannot be achieved without decent work, gender equality and empowerment of all women [3]. It must transgress the situations of discrimination and inequality existing for reasons of gender [3] reflected in organizations, in the family and in the society [4].

World Tourism Organization (UNWTO) defines gender equality as: The equal rights, responsibilities and opportunities of women and men and girls and boys. Equality does not mean that women and men will become the same but that women's and men's rights, responsibilities and opportunities will not depend on whether they are born male or female. Gender equality implies that the interests, needs and priorities of both women and men are taken into consideration, recognizing the diversity of different groups of women and men. Gender equality is not a women's issue but should concern and fully engage men as well as women. Equality between women and men is seen both as a human rights issue and as a precondition for, and indicator of, sustainable people-centered development [5] 
(p. 161). The definition provided by UNWTO of women empowerment is their gaining power and control over their own lives. It involves awareness-raising, building selfconfidence, expansion of choices, increased access to and control over resources and actions to transform the structures and institutions which reinforce and perpetuate gender discrimination and inequality. This implies that to be empowered they must not only have equal capabilities (such as education and health) and equal access to resources and opportunities (such as land and employment), but they must also have the agency to use these rights, capabilities, resources and opportunities to make strategic choices and decisions (such as is provided through leadership opportunities and participation in political institutions) [5] (p. 161).

Tourism is a sector where $59 \%$ of people employed are women [5], even more in accommodation (61\%), and in travel agencies and tour operators (64\%) [6]. 53\% of unregistered workers in accommodation and food service activities in the EU are women [6]. In a sector characterized by extensive job rotation, seasonality, precarious contracts and part-time work, women are even more affected by these conditions than men. Among other reasons, because men work in more developed tourist areas and where workers are better paid [7]. Although women tourism employees generally achieve higher levels of education that men [8], women are both horizontal and vertical segregated [9], with a result of a gender pay gap of $14.7 \%$ [5]. Earning lower wages than their peers, even doing the same work [2], and increasing this gender pay gap with the level of education [7]. Managerial positions are dominated by men even though studies show that companies with female representation on managerial positions performing better than those without women [10]. When they manage to reach those positions, women have much higher pressure than men [10], They are relegated to lower-level positions, concentrated in certain job niches often associated with an extension of work household chores [11] such as cleaning of spaces, kitchen, housekeepers, cabin crew work, etc. Is significant of this concentration the fact that approximately $79 \%$ of flight attendants in US are women, while approximately $5 \%$ of airline pilots and $1.43 \%$ captains are women [12]. Women have fewer opportunities to promote due to gender stereotyping and discrimination and an exclusion of women from informal networks that contribute to gender segregation [8]. Women workers continue to account for most part-time contracts [11] because a lack of opportunities to work full-time, on the contrary, most men part-time workers chose it because they are studying or training [7].

Despite that tourism companies run by a woman are frequently more successful than those led by man [8], women are underrepresented as social entrepreneurs, and there are a smaller number of female start-ups [13]. Even when they own businesses, they find it harder to access to credit [9]. Although an increasing number of women become entrepreneurs in the tourism sector, and that is very positive, most of this entrepreneurship are because of demanding and inflexible work environments that they find in salaried employment, to escape the glass ceiling and to gain flexibility [4]. Women look for flexibility because tourism requires long working hours, work in shifts, at night, on Saturdays and Sundays. These conditions complicate work-life balance [7] damaging women more than men [9], so the search for flexibility is another of the traps of inequality. It is not something chosen by women, is a forced decision, especially if they want to be mothers. Be a worker with maternity projects can be an obstacle to these type of jobs [11]. In fact, having children may have a greater impact on women's careers than on men's [4] due to domestic responsibilities, and by societal perceptions of motherhood. That push women to pause their professional career once they have children, creating a disadvantage in future promotions [10]. Is not until recently that there is an acknowledgement that family and professional life cannot be separated, as it had been for years when work was something recognized only to men, left women in the realm of work at home. But these societal perceptions are still discouraging some women from seeking promotions in their organizations [4,14], becoming entrepreneurs or even from growing in public spheres [10].

Most related work health problems in tourism are suffered by women [15], the 2019 UNWTO global report on women in tourism [5] related to the stress specifically suffer by 
women in the touristic sector, and linked stress with work-life balance due to women's high burden of care work. In the framework of global crises, public Administration' cuts in public spending on care, such as dependency or social services. The burden of care shifts to households falls mainly on women [16-18] which increase women's unpaid work [11]. In the frame of the last crisis produced by Covid-19 the need to educate children without institutional support, have reduced even more the remunerated working hours, and have increased stress for women [17]. Women workers in tourism industry even experience sexual harassment violence that contributes to intensifying inequality [19] and aggravates female workers' health problems.

In the academic and research field in tourism there is also inequalities, gendered processes privilege men in tourism, hospitality and events research and studies. Gender papers tend to attract less citations than the average, even when published in highly ranked journals $[14,20]$. Over $40 \%$ of tourism gender papers are totally uncited, and less than $10 \%$ of the studies of tourism and gender appear in gender or feminist studies journal [14]. There is an intense gender gap in conference invited speakers, top editorial positions, and fellowship in the academy [21], even in global tourism institutions such as the UNWTO [20].

Men are crucial agents of change [10], that is why it is necessary the normalization of both men and women in varied industry roles [12] to help overcome the gender stereotypes that still exist in society. In the family sphere, among friends, in the workplace or in business [10], even in education [22] there is still strengthened gender stereotype [10]. Gender stereotypes can be defined as simplistic generalizations of gender attributes, the differences and roles of women and men [23] (p. 38), they are one of the most common characteristics of gender inequality [22]. Stereotypes reinforce the view that women take care of people and help them, while men take control and focus on the task [10]. These gender-based stereotypes delimit people's possibilities and influence their preferences, skills, emotions, or aspirations [22]. In the case of the tourism and hospitality sector roles of female workers are associated with an extension of work household chores, and male workers preferred by many tourists as tour guides [2]. These stereotypes evoke not only the roles assigned to female and male workers, but also evoke women' appearance as 'pretty', 'slim' or 'young' [12].

Tourism offers great opportunities for gender equality [9] and women empowerment, providing women with an independent income, more power as breadwinners, and increasing social mobility [19] which, in turn, contributes to the countries' development. Despite this, there is a lack of a gender perspective in training curricula, social research [3], public policies, collective employment agreements, in organizations, in the family and in the society. And what is more, the Covid-19 pandemic has aggravated gender inequalities and the lack of female empowerment [10].

Given the data presented, it is especially important to carry out research on gender studies. Despite a marked increase in research in the field of tourism, especially in the wake of the Covid-19 pandemic, the number of gender equality research remains proportionately low. Therefore, it is of great interest to know how the gender equality research is progressing. This research focuses on this, and more specifically on the afore mentioned sector, tourism.

\section{Materials and Methods}

A systematic review will be carried out because it is an essential tool for summarizing evidence accurately and reliably [24]. To our knowledge this is the first review about gender equality in tourism sector, so is a new systematic review. Following the PRISMA Statement [25], the PRISMA 2020 checklist has been completed, and the flow diagram included in this article.

To carried out the systematic review, a comprehensive bibliometric analysis has been carried out, including two main techniques: Evaluative methods, and relational methods [26,27]. Is has been decided to use these techniques because, as stated by Koseoglu, et al. [27]: "the bibliometric relational techniques explore relationships among 
the research fields, the emergence of new research themes and methods, or co-citation and co-authorship pattern" (p. 182). The co-word structure is a content analysis technique which analyses the words frequency in a text and seeks to find patterns to build concepts in a certain area $[27,28]$. The specific type of content analysis employed in the present work was categorical content analysis, which consists of dismembering the texts into units, or categories, according to pre-established criteria [29]. According to Molinos, Mesquita \& Hoff [30] this kind of analysis is a powerful tool to detected key-themes in scientific articles.

The data collection procedures were carried out in June 2021, consisted of a search for work on gender equality in the tourism sector, written in English and published in the Scopus database until June 2021. The Scopus database was chosen as a data source because it was one with the largest set of citation data and high-quality abstracts of peer-reviewed literature on the web [31]. To filter the studies on the subject, the search was limited to works that contain "gender + equality + tourism" within their title, abstract and keywords.

As presented in the PRISMA Flow Diagram (Figure 1), 97 records have been identified from Scopus, after removed 5 because they are Conference papers and neither of them have abstract, a total of 92 works is obtained. This sample is used to carry out quantitative analyses.

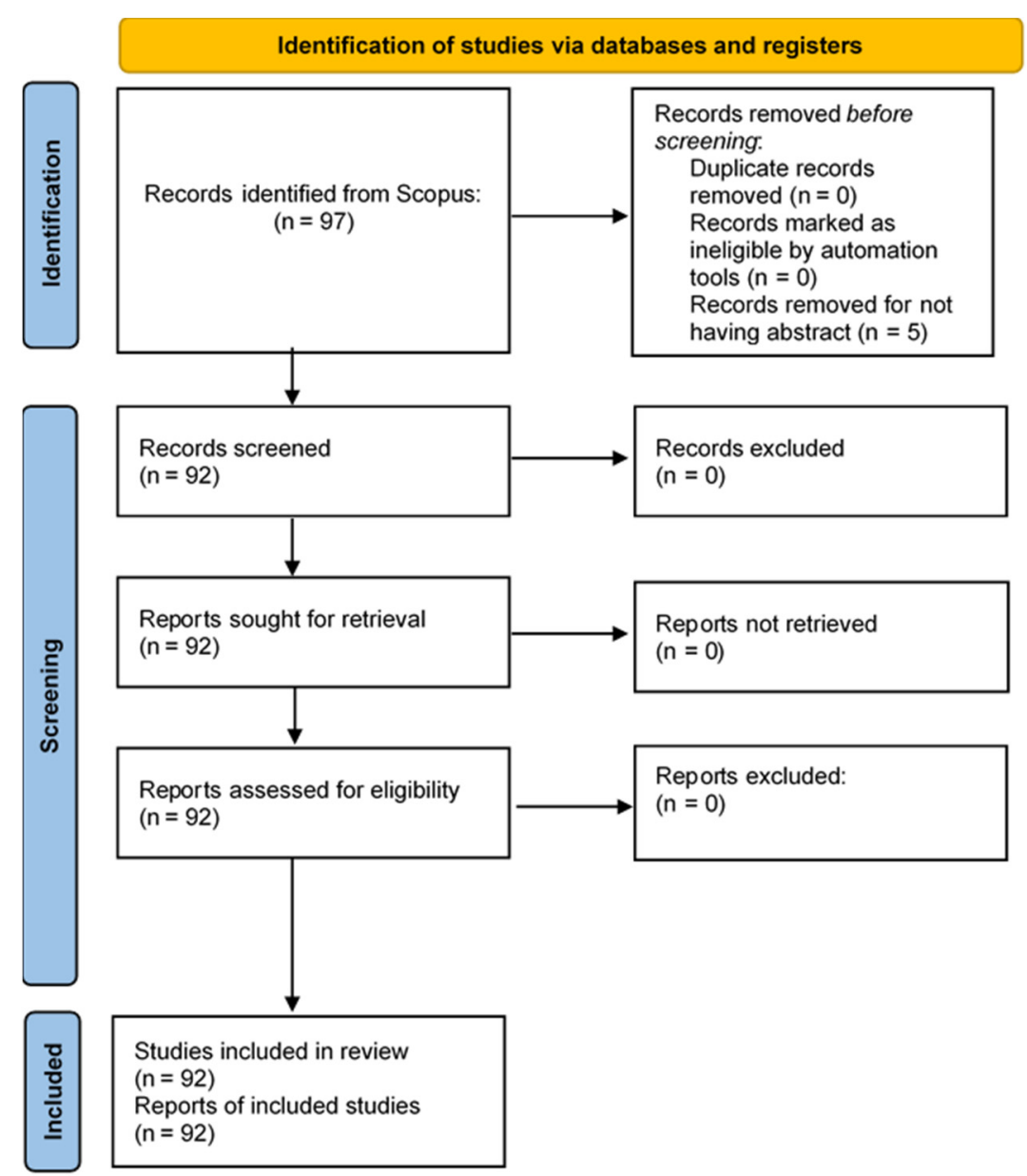

Figure 1. PRISMA 2020 flow diagram for new systematic reviews which included searches of databases and registers only.

For the content analysis it is decided to analyze the most recent works, published in 2021, knowing the most current trends in this field. In this case the sample amounts to 11 works, being one of the years with more publications in this field (considering that it has not finished the year).

Thus, the bibliographic information of the articles collected was organized, classified, and summarized in an Excel spreadsheet. Then, word frequency analysis and analysis of 
key topics were applied to explore the contents and relationships between the research topic and its associated topics and methods. Word frequency analysis and content analysis method were used to quantify qualitative data [32]. The bibliometric systematic review, the variables used were identified in co-word analysis and the 92 articles, which were the source of information for this research, were comprehensively reviewed considering other similar studies [33]. For a better understanding of the data obtained, these have been presented with the support of various tables and figures, accompanied to each of them of their respective explanation.

\section{Results}

\subsection{Productivity and Impact Metrics}

The data analyzed show a growing trend in the work on gender equality in tourism, especially since 2017. Only in the last year and a half (2020-June 2021) has been published the $40.2 \%$ of research in this field. The maximum value up to date was reached in 2020 , with a total of 26 papers. While the average of the previous decade was less than an annual publication (0.8 per year) (Table 1$)$.

Table 1. Academic publications of "gender equality tourism".

\begin{tabular}{cc}
\hline Year & No. Publications \\
\hline 2021 & 11 \\
2020 & 26 \\
2019 & 9 \\
2018 & 9 \\
2017 & 10 \\
2016 & 4 \\
2015 & 6 \\
2014 & 2 \\
2013 & 3 \\
2012 & 1 \\
2011 & 2 \\
$2001-2010$ & 8 \\
1996 & 1 \\
Total & 92 \\
\hline
\end{tabular}

In terms of journal productivity, as shown in Figure 2, the Journal of Sustainable Tourism clearly has the largest number of publications (12), followed by Annals of Tourism Research, Current Issues in Tourism and Sustainability, with 4 jobs each.

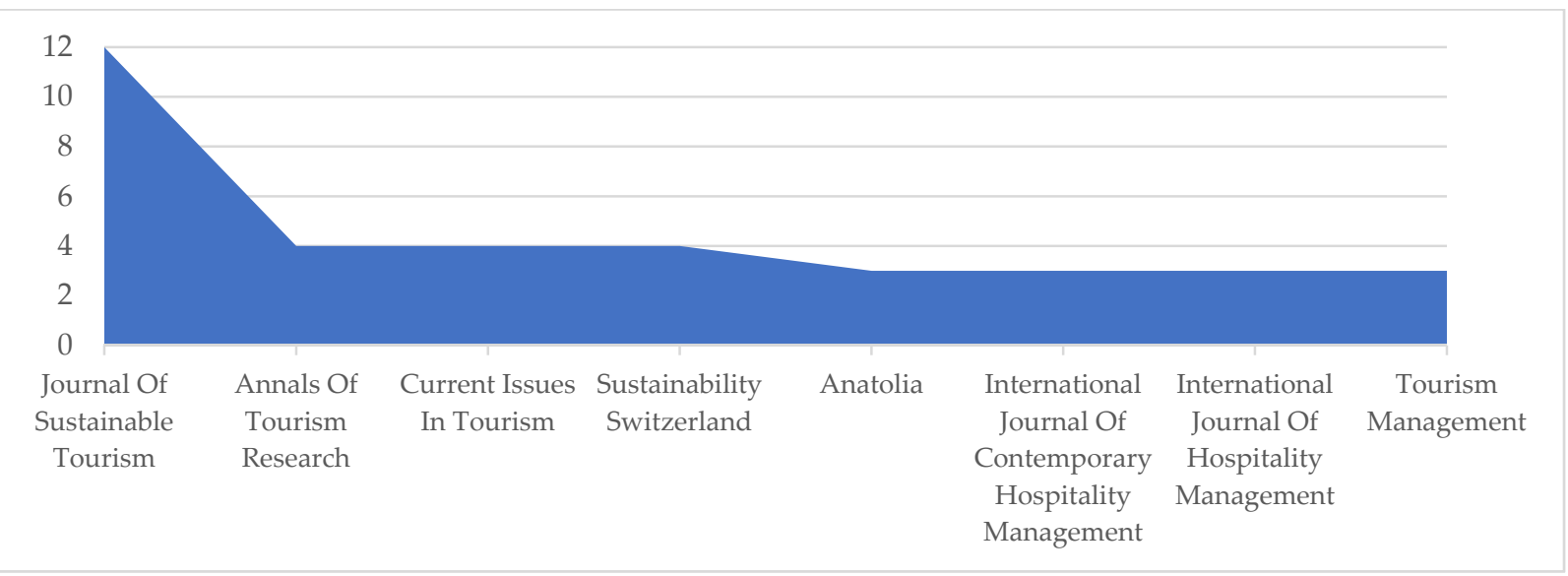

Figure 2. The most publishing journals contributing to the area of "gender equality tourism" (more than 3 articles published). 
Regarding the thematic category of the journals in which most of the articles were published, "Social Sciences" leads the ranking with 63 articles, followed by "Business, Management and Accounting" (54 articles). With a notable quantitative leap is "Environmental Science" (12 articles) (Figure 3).

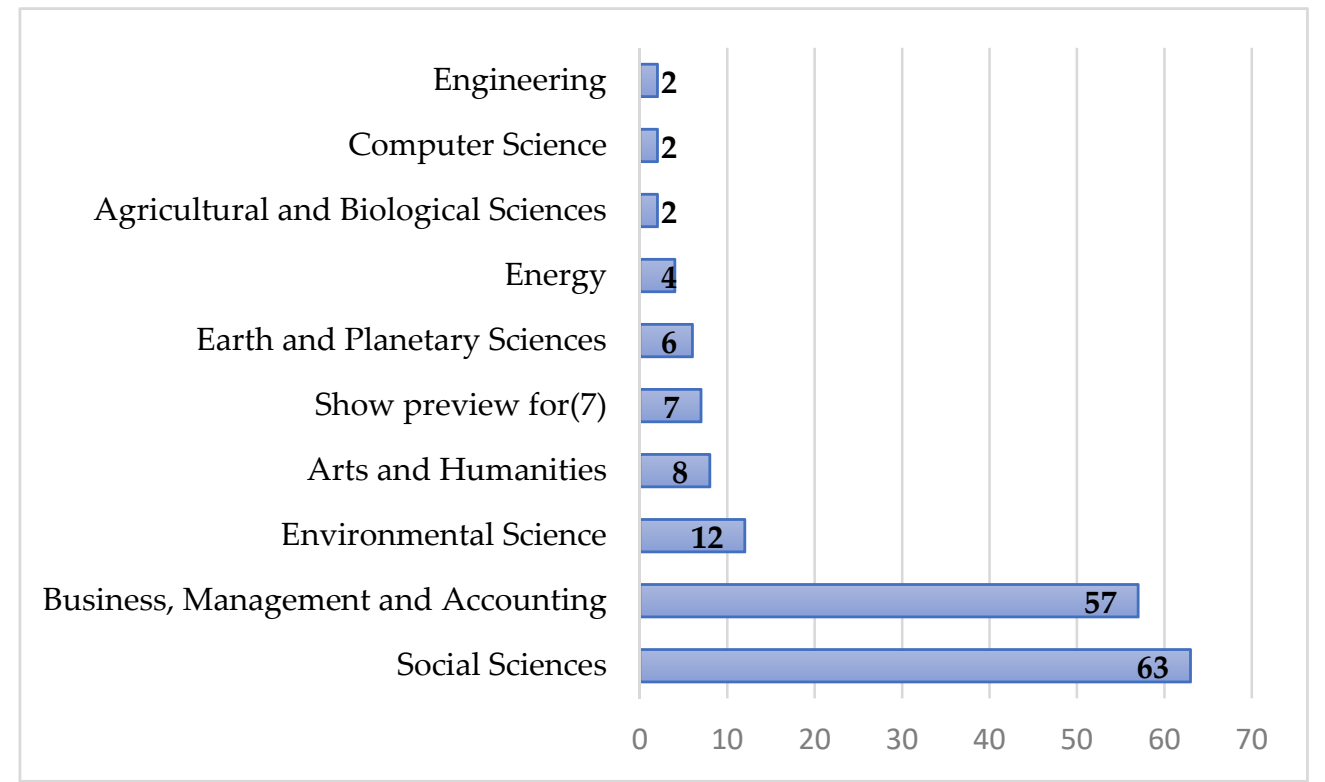

Figure 3. Top subject categories of journals ordered by published articles on "gender equality tourism" (almost 2 articles published).

The articles were also analyzed in terms of the geographic location of the research institutions to which their authors are associated. Figure 4 shows the main countries in terms of the number of articles published in "gender equality tourism". It is noteworthy that United Kingdom has the best record in terms of publications, with 16 articles, something unusual, since the United States usually leads all the rankings. The second most prolific country is Spain, which has contributed 15 articles during the period under review. Then Australia, with 11 jobs, and Portugal and United States with 6 jobs each.

Finally, the sample was analysed in terms of the most prolific authors. In this sense, not only the number of articles published by each author was considered, but also the number of citations received by each article and author, since it is a more accurate indicator of the impact factor of the authors and articles.

As shown in Table 2, there are 4 most prolific authors, highlighting Ferguson, L. as in addition to publishing 3 works, has obtained more than 100 citations. 


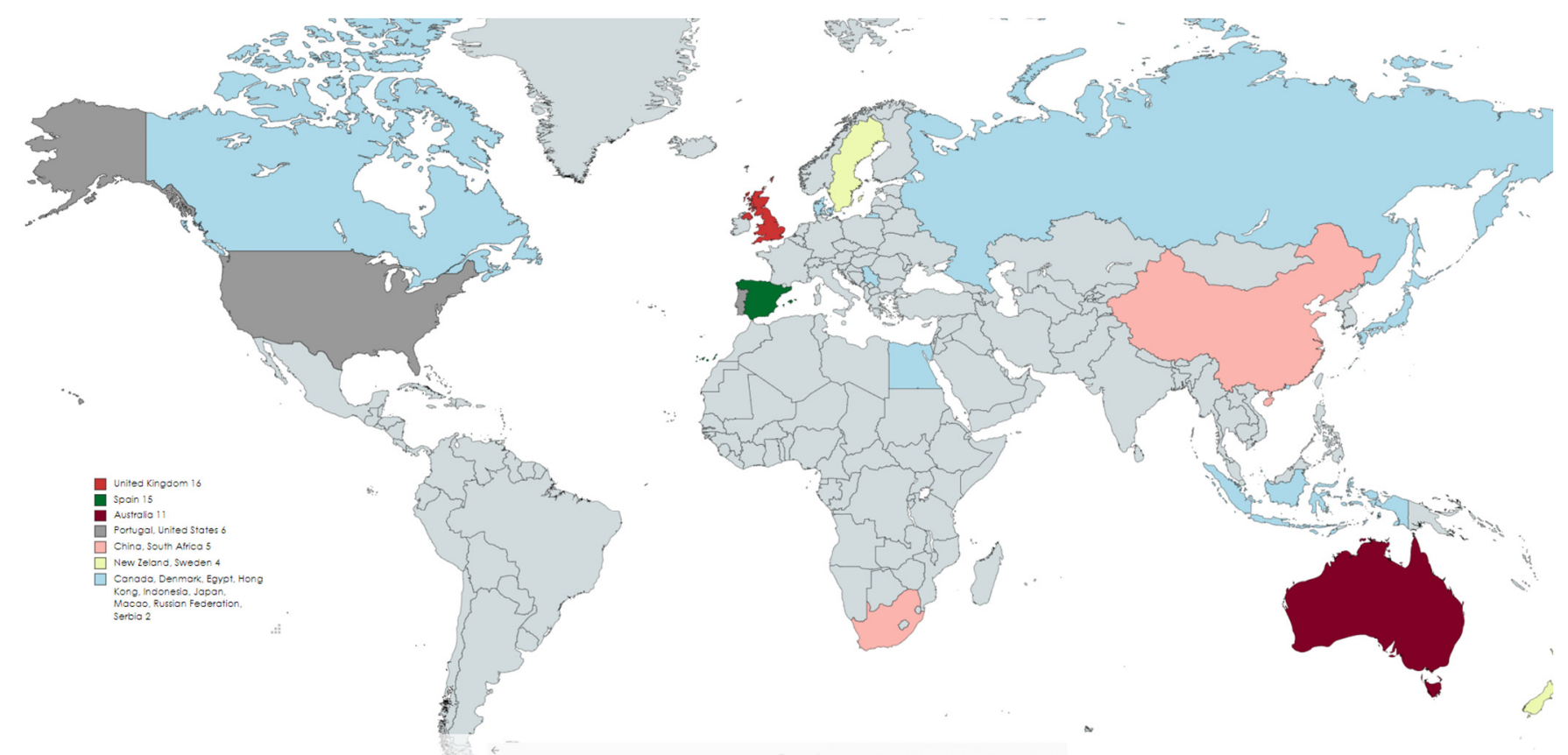

Figure 4. The most prolific countries in the field of gender equality tourism.

Table 2. Most prolific and influential authors on gender equality tourism (GET).

\begin{tabular}{ccccccc}
\hline \multicolumn{2}{c}{ Top 11 Authors Rank $(\boldsymbol{n}=\mathbf{9 2})$} & \multicolumn{3}{c}{ Performance of the Authors GET Papers } \\
\hline \multirow{2}{*}{ Ranking } & Author & $\begin{array}{c}\text { Absolute } \\
\text { Frequency }\end{array}$ & \% & Total Citations & $\begin{array}{c}\text { No. of First } \\
\text { Authorship Papers }\end{array}$ & Publication Year \\
\hline 1 & Costa, C. & 3 & $3.3 \%$ & 37 & 1 & $2016,2018,2019$ \\
2 & Ferguson, L. & 3 & $3.3 \%$ & 102 & 3 & 2011,2015 \\
3 & Khoo-Lattimore, C. & 3 & $3.3 \%$ & 44 & 1 & 2017,2019 \\
4 & De Jong, A. & 3 & $3.3 \%$ & 5 & 0 & 2020,2021 \\
5 & Alarcón, D.M. & 2 & $2.2 \%$ & 68 & 1 & 2015,2019 \\
6 & Bakas, F.E. & 2 & $2.2 \%$ & 6 & 2 & 2018 \\
7 & Biran, A. & 2 & $2.2 \%$ & 36 & 0 & 2017 \\
8 & Breda, Z. & 2 & $2.2 \%$ & 14 & 0 & 2016,2018 \\
9 & Chambers, D. & 2 & $2.2 \%$ & 36 & 0 & 2017 \\
10 & Cohen, S. & 2 & $2.2 \%$ & 1 & 0 & 2021 \\
11 & Durão, M, & 2 & $2.2 \%$ & 14 & 1 & 2016,2018 \\
12 & Figueroa-Domecq, C. & 2 & $2.2 \%$ & 51 & 1 & 2020 \\
13 & Je, J.S. & 2 & $2.2 \%$ & 12 & 0 & 2019,2020 \\
14 & Kimbu, A.M. & 2 & $2.2 \%$ & 1 & 1 & 2021 \\
15 & Munar, A.M. & 2 & $2.2 \%$ & 36 & 1 & 2017 \\
16 & Yang, E.C.L. & 2 & $2.2 \%$ & 8 & 2 & 2017,2019 \\
17 & Zhang, J. & 2 & $2.2 \%$ & 4 & 0 & 2020,2021 \\
18 & Zhang, Y. & 2 & $2.2 \%$ & 4 & 2020,2021 \\
\hline
\end{tabular}

\subsection{Word Frequency Analysis}

The frequency of words was analysed first through word counts of the 92 titles, being a total of 1161 words. The sample of abstracts included 18,031 words. Finally, a total of 788 keywords were counted, an average of 4.4 per article. Articles, prepositions, and pronouns have been dispensed with for the analysis of these words. Table 3 summarizes the most common words in titles, abstracts, and keywords. As expected, "tourism", "gender" and "equality" top the ranking, followed by "development" and "women". 
Table 3. Title/Abstract and keywords analysis "gender equality tourism".

\begin{tabular}{|c|c|c|c|c|c|c|c|c|c|c|c|}
\hline \multicolumn{2}{|c|}{ TOP 10 Words on Titles } & \multicolumn{2}{|c|}{$n=1161$} & \multicolumn{2}{|c|}{ TOP 15 Words on Abstracts } & \multicolumn{2}{|c|}{$n=18,031$} & \multicolumn{2}{|c|}{ TOP 16 Keywords } & \multicolumn{2}{|c|}{$n=788$} \\
\hline Rank: & $\begin{array}{l}\text { Variable } \\
\text { Name: }\end{array}$ & $\begin{array}{l}\text { Absolute } \\
\text { Frequency: }\end{array}$ & $\begin{array}{l}\text { Relative } \\
\text { Frequency: }\end{array}$ & Rank: & $\begin{array}{l}\text { Variable } \\
\text { Name: }\end{array}$ & $\begin{array}{l}\text { Absolute } \\
\text { Frequency: }\end{array}$ & $\begin{array}{l}\text { Relative } \\
\text { Frequency: }\end{array}$ & Rank: & $\begin{array}{l}\text { Variable } \\
\text { Name: }\end{array}$ & $\begin{array}{l}\text { Absolute } \\
\text { Frequency: }\end{array}$ & $\begin{array}{l}\text { Relative } \\
\text { Frequency: }\end{array}$ \\
\hline 1 & Tourism & 55 & $4.7 \%$ & 1 & Tourism & 317 & $1.8 \%$ & 1 & Gender & 72 & $9.1 \%$ \\
\hline 3 & Equality & 19 & $1.6 \%$ & 3 & Women & 143 & $0.8 \%$ & 3 & Equality & 28 & $3.6 \%$ \\
\hline 4 & Women & 14 & $1.2 \%$ & 4 & Equality & 118 & $0.7 \%$ & 4 & Development & 21 & $2.7 \%$ \\
\hline 5 & Development & 14 & $1.2 \%$ & 5 & Research & 89 & $0.5 \%$ & 5 & Women & 20 & $2.5 \%$ \\
\hline 6 & Study & 12 & $1.0 \%$ & 6 & Development & 87 & $0.5 \%$ & 6 & Empowerment & 13 & $1.6 \%$ \\
\hline 8 & Research & 8 & $0.7 \%$ & 8 & Social & 58 & $0.3 \%$ & 8 & Social & 8 & $1.0 \%$ \\
\hline 9 & Hospitality & 7 & $0.6 \%$ & 9 & Sustainable & 55 & $0.3 \%$ & 9 & Management & 6 & $0.8 \%$ \\
\hline 9 & Empowerment & 7 & $0.6 \%$ & 10 & Female & 46 & $0.3 \%$ & 9 & Entrepreneurship & 6 & $0.8 \%$ \\
\hline \multirow[t]{5}{*}{10} & Sustainable & 6 & $0.5 \%$ & 11 & Analysis & 44 & $0.2 \%$ & 9 & Hospitality & 6 & $0.8 \%$ \\
\hline & & & & 12 & Business & 39 & $0.2 \%$ & 10 & Employment & 5 & $0.6 \%$ \\
\hline & & & & 13 & Industry & 38 & $0.2 \%$ & 10 & Research & 5 & $0.6 \%$ \\
\hline & & & & 14 & Family & 36 & $0.2 \%$ & 10 & Feminism & 5 & $0.6 \%$ \\
\hline & & & & 15 & Empowerment & 35 & $0.2 \%$ & 10 & Female & 5 & $0.6 \%$ \\
\hline
\end{tabular}




\subsection{Key Theme Analysis}

To analyze the key themes over time, a temporal analysis of the abstracts of the 92 articles has been carried out. There are 4 periods from the first publication. The first publication of 1996 is discarded because it is not linked to the topic, and because there is a significant time gap until the following publication in 2001:

- 2001-2010;

- 2011-2015;

- 2016-2018;

- 2019-2021 (hasta el mes de junio).

The first period, of 10 years, presents only 8 published works, less than 1 per year. The terms tourism, gender, women and social are common in these early investigations, in addition to others less frequent such as management or development. From 2011 to 2015 the number of papers published increased to 14. The topics analysed in the previous period are maintained and new ones emerge such as equality, community, education, or female. Between 2016 and 2018, 23 works are published. In addition to the thematic line followed so far, it is introduced with greater weight the term development. There are jobs linked to empowerment, economic and sustainability. The last period is the most prolific, with 46 works, in which issues related to family and hospitality also emerge, as well as aspects with a more economic vision such as business, industry or employment (Figure 5).

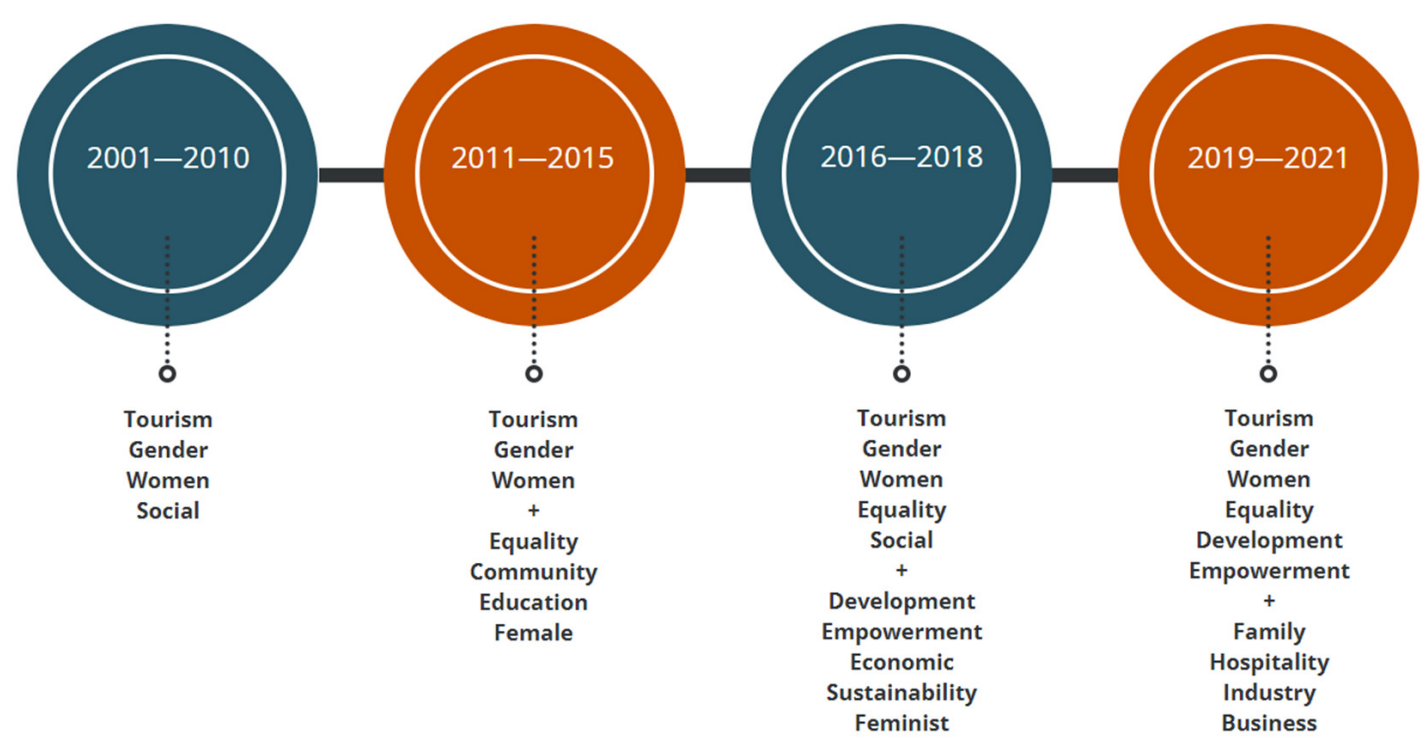

Figure 5. Key theme timeline 2001-2021.

\subsection{Content Analysis}

For the content analysis, as mentioned in the methodology of the work, the sample of the last year (2021) has been used, of 9 works ( 2 are discarded, one for being the proceedings of a congress, and another for not being directly linked to the object of study). The abstracts of these works are analyzed, looking for the themes of study. The results of the content analysis with the most recent articles in this field are presented in Table 4. In the table appear the publications of the most prolific authors in this field, the titles and the themes of those works. It follows that one of the sectors within the tourism sector that arouses most interest in terms of the gender gap is that of air transport, where cabin crew is still a predominantly female position [12]. There is also a continuing gender imbalance in the tourism sector, with more precarious female jobs, and fewer women in management and management positions. Geographically, regions such as Egypt or Unit Arab Emirates have special interest, where gender differences are even more noticeable. It also analyses this gender difference in emerging economies and the emergence of the term empowerment 
in the tourism sector, linked to the need of women to continue fighting for equality in this sector.

Table 4. Content analysis of the most recent GET publications $(n=9)$.

\begin{tabular}{|c|c|c|}
\hline Title & Authors & Theme \\
\hline $\begin{array}{l}\text { Reshaping gender in airline } \\
\text { employment }\end{array}$ & $\begin{array}{l}\text { Smith W.E., Cohen S., Kimbu A.N., de } \\
\text { Jong A. }\end{array}$ & $\begin{array}{l}\text { - } \quad \text { Air transport and tourism } \\
\text { - } \quad \text { Gender balance } \\
\text { archetypically feminine }\end{array}$ \\
\hline $\begin{array}{l}\text { Women managers in tourism: } \\
\text { Associations for building a } \\
\text { sustainable world }\end{array}$ & Freund D., Hernandez-Maskivker G. & $\begin{array}{ll}\text { - } & \text { Tourism sector } \\
\text { - } & \text { Precarious position women } \\
\text { - } & \text { In management women are seriously } \\
& \text { underrepresented }\end{array}$ \\
\hline $\begin{array}{l}\text { How international tourism impacts } \\
\text { political and ethno-religious issues in } \\
\text { Africa? A case study of } \\
\text { inter-governmental authority on } \\
\text { development (IGAD) }\end{array}$ & Suchkova A.A. & $\begin{array}{ll}- & \text { Tourism sector } \\
\text { - } & \text { Inclusive development }\end{array}$ \\
\hline $\begin{array}{l}\text { Good idea but not here! a pilot study } \\
\text { of swedish tourism stakeholders' } \\
\text { perceptions of halal tourism }\end{array}$ & Abbasian S. & $\begin{array}{l}\text { - The perception of Halal tourism in Sweden } \\
\text { among representatives of } \\
\text { tourism stakeholders }\end{array}$ \\
\hline $\begin{array}{l}\text { A qualitative comparative analysis of } \\
\text { tourism and gender equality in } \\
\text { emerging economies }\end{array}$ & Zhang J., Zhang Y. & $\begin{array}{l}\text { A comparative analysis of tourism and } \\
\text { gender equality in emerging economies }\end{array}$ \\
\hline $\begin{array}{l}\text { Gendered Instagram representations } \\
\text { in the aviation industry }\end{array}$ & $\begin{array}{l}\text { E. Smith W., Kimbu A.N., de Jong A., } \\
\text { Cohen S. }\end{array}$ & $\begin{array}{l}\text { - } \quad \text { Air transport and tourism } \\
\text { A feminist poststructuralist approach to } \\
\text { deconstruct normative gendered } \\
\text { assumptions that exist within the aviation } \\
\text { sector's use of Instagram }\end{array}$ \\
\hline $\begin{array}{l}\text { A return to innocence: Guimi tourism } \\
\text { and women empowerment }\end{array}$ & Hao F., Zhang S., Xiao H. & $\begin{array}{l}\text { A context-specific understanding of Guimi } \\
\text { tourism and theoretically contributed to } \\
\text { women empowerment and tourism }\end{array}$ \\
\hline $\begin{array}{l}\text { There is greater gender equality in } \\
\text { mountaineering research }\end{array}$ & Apollo M. & $\begin{array}{l}\text { - The gender of authors who are working on } \\
\text { mountaineering tourism issues }\end{array}$ \\
\hline $\begin{array}{l}\text { Women's empowerment and tourism } \\
\text { development: A cross-country study }\end{array}$ & $\begin{array}{l}\text { Abou-Shouk M.A., Mannaa M.T., } \\
\text { Elbaz A.M. }\end{array}$ & $\begin{array}{l}\text { - Women's empowerment } \\
\text { The influence of women's empowerment } \\
\text { on tourism development across three } \\
\text { different Arab countries: Egypt, the United } \\
\text { Arab Emirates, and Oman }\end{array}$ \\
\hline
\end{tabular}

\section{Discussion and Conclusions}

Gender inequality is common to all sectors, but in the tourism industry it is even more pronounced. In a sector characterized by extensive job rotation, seasonality, precarious contracts and part-time work, women are even more affected by these conditions than men. They, moreover, do not have to bear only the bad conditions of the sector, but they must bear the failures of the public administrations. Especially in global crises, taking care of the household tasks and the care of relatives and dependents, which hampers their chances of promotion and improvement.

There has been a year-on-year increase in publications related to gender equality in the field of tourism, especially from 2017. Despite this, the present research reveals that there are still few studies focused on gender in the field of tourism, and that only in the last time have they been linked to the family. Because is not until recently that there is an acknowledgement that family and professional life cannot be separated, as they had been 
for years when work was something recognized only to men and left women in the realm of work at home, as presented in the introduction of this research.

The bibliometric analysis carried out shows that most of the publications related to gender equality and tourism indexed in Scopus have been published mostly in the Journal of Sustainable Tourism. There are not any authors focusing their publications on gender equality in the field of tourism, as shown by the fact that the maximum number of publications per author is 3 . This could be due to the fact analyzed in the introduction that gender papers tend to attract less citations than the average, and over $40 \%$ of tourism gender papers are totally uncited. The thematic category of the journals in which most of the articles were published is "Social Sciences", followed by "Business, Management and Accounting". The country with most articles published in gender equality is United Kingdom, followed by Spain. The most common words in titles, abstracts, and keywords, are "tourism", "gender" and "equality" followed by "development" and "women". The word "family" only appears on the most common words in abstracts, being one of the latest.

The key theme varies during the analyzed periods, is not until the period from 2011 to 2015 that appears the theme equality in the research, as well as the terms community or education. The literature reviewed in the introduction indicates that there is still a lack of a gender perspective in training curricula. But the fact that terms as education start to appear in gender research, is an indication that equality becomes a matter for all. In which it is necessary to educate, and not as in previous periods where women and equality things were left in the private environment. Between 2016 and 2018 the theme development emerges with greater weight because of the recognized importance of women's work and contribution to development. From 2018 emerges the theme family, empowerment, and sustainability without leaving aside the purely economic as business, industry, or employment. The develop of the term sustainability on the last years, specially from the approval of the Agenda 2030, and a more intense focus on economic and social sustainability matters, instead that on environment at is had been for many years, can explain the use of these new terms. The content analysis shows that the main interest in terms of the gender gap is that of air transport, where cabin crew is still a predominantly female position. Coincident with the literature presented in the introduction in which it is stated that female workers are concentrated in jobs often associated with an extension of work household chores.

Main limitation of this study is the delimitation of the work to be analysed through the selected database, Scopus. Although this is one of the most complete bases with the largest number of scientific and academic publications, there may be other works not indexed in this database that have been ignored. As a second limitation, mention the selected words for the filtering of works. The most significant words have been chosen for this study are "gender + equality + tourism", and the search has been extended to titles, keywords and abstracts, but there may be works linked to the topic that do not explicitly use these words. Based on these two limitations, they are proposed as future research lines, first, a research that expands the number of papers analysed using other databases in addition to Scopus, for example, Web of Science. Also expand searches using various combinations of filtering words (equity, feminism, inequality, women...).

It is hoped an increase in the number of publications related to gender equality driven by the Agenda 2030, as well as by a greater awareness on the part of society, a equality trend among the youngest in recent years, and by an increasing attention on gender-based violence. It is not only expected that the number of publications will increase, but that they are considered completely necessary, from all areas, but even more from the point of view of tourism. At a time when the academic and professional sector is committed to a renewal of tourism and seeks greater sustainability. This renewal must go hand in hand with equality, because otherwise a part of society that is burdened with jobs both inside and outside the home would be excluded from it. These necessary changes must also include the attempt to decrease the gender gap in the tourism academy, with a higher 
presence of women in top editorial positions, in conference as invited speakers or with higher scholarships at the academy.

Author Contributions: Conceptualization N.A.-V. and A.O.-C.; methodology N.A.-V.; validation, N.A.-V. and J.A.F.-B.; formal analysis N.A.-V.; investigation, A.O.-C.; data curation, N.A.-V.; writingoriginal draft preparation N.A.-V. and A.O.-C.; writing-review and editing, A.O.-C.; visualization, J.A.F.-B.; supervision N.A.-V. and A.O.-C.; project administration N.A.-V. and A.O.-C. All authors have read and agreed to the published version of the manuscript.

Funding: This research received no external funding.

Institutional Review Board Statement: Not applicable.

Informed Consent Statement: Not applicable.

Conflicts of Interest: The authors declare no conflict of interest.

\section{References}

1. United Nations. Transforming Our World: The 2030 Agenda for Sustainable Development. A/RES/70/1. 2015. Available online: https://sdgs.un.org/2030agenda (accessed on 15 July 2021).

2. Zhang, J.; Zhang, Y. A Qualitative Comparative Analysis of Tourism and Gender Equality in Emerging Economies. J. Hosp. Tour. Manag. 2021, 46, 284-292. [CrossRef]

3. Cañada, E.; Alarcón, D. Gender Dimensions in Tourism Work; Alba Sud: Barcelona, Spain, 2018.

4. Carvalho, I.; Costa, C.; Lykke, N.; Torres, A. Agency, Structures and Women Managers' Views of Their Careers in Tourism. Women's Stud. Int. Forum 2018, 71, 1-11. [CrossRef]

5. World Tourism Organization (UNWTO). Global Report on Women in Tourism, 2nd ed.; World Tourism Organization (UNWTO): Madrid, Spain, 2019. [CrossRef]

6. Williams, C.; Horodnic, I. Tackling Undeclared Work in the Tourism Sector. 2020. Available online: https://ec.europa.eu/social/ BlobServlet?docId=22868\&langId=en (accessed on 15 July 2021).

7. Costa, C.; Carvalho, I.; Breda, Z. Gender Inequalities in Tourism Employment: The Portuguese Case. Rev. Tur. Desenvolv. 2011, 15, $39-54$.

8. Kogovšek, M.; Kogovšek, M. Hospitality and Tourism Gender Issues Remain Unsolved: A Call for Research. Quaestus 2012, 6, 194-203.

9. Rinaldi, A.; Salerno, I. The Tourism Gender Gap and Its Potential Impact on the Development of the Emerging Countries. Qual. Quant. 2020, 54, 1465-1477. [CrossRef]

10. Freund, D.; Hernandez-Maskivker, G. Women Managers in Tourism: Associations for Building a Sustainable World. Tour. Manag. Perspect. 2021, 38, 100820. [CrossRef]

11. Martínez-Gayo, G.; Martínez Quintana, V. Precariedad Laboral En El Turismo Español Bajo La Perspectiva de Género. Pasos 2020, 18, 649-665. [CrossRef]

12. Smith, W.E.; Cohen, S.; Kimbu, A.N.; de Jong, A. Reshaping Gender in Airline Employment. Ann. Tour. Res. 2021, 89, 103221. [CrossRef]

13. Butkouskaya, V.; Romagosa, F.; Noguera, M. Obstacles to Sustainable Entrepreneurship amongst Tourism Students: A Gender Comparison. Sustainability 2020, 12, 1812. [CrossRef]

14. Pritchard, A. Predicting the next Decade of Tourism Gender Research. Tour. Manag. Perspect. 2018, 25, 144-146. [CrossRef]

15. Hsieh, Y.-C.; Apostolopoulos, Y.; Sönmez, S. Work Conditions and Health and Well-Being of Latina Hotel Housekeepers. J. Immigr. Minority Health 2016, 18, 568-581. [CrossRef]

16. ONU Mujeres México. La Corresponsabilidad en los Hogares. Available online: https://mexico.unwomen.org//digiteca/ publicaciones/2020-nuevo/marzo-2020/covid19-corresponsabilidad-en-los-hogares (accessed on 23 February 2021).

17. Power, K. The COVID-19 Pandemic Has Increased the Care Burden of Women and Families. Sustain. Sci. Pract. Policy 2020, 16, 67-73. [CrossRef]

18. Tremeau, V. COVID-19: Es Imperativo Transformar el Trabajo de Cuidados, las Mujeres Sufren la Mayor Carga. Available online: https:/ / news.un.org/es/story/2020/08/1479192 (accessed on 23 February 2021).

19. Eger, C. Gender Matters: Rethinking Violence in Tourism. Ann. Tour. Res. 2021, 88, 103143. [CrossRef]

20. Mooney, S.K. Gender Research in Hospitality and Tourism Management: Time to Change the Guard. IJCHM 2020, 32, 1861-1879. [CrossRef]

21. Munar, A.; Biran, A.; Budeanu, A.; Caton, K.; Chambers, D.; Dredge, D.; Gyimóthy, S.; Jamal, T.; Larson, M.; Lindström, K.; et al. The Gender Gap in the Tourism Academy: Statistics and Indicators of Gender Equality; While Waiting for the Dawn: Copenhagen, Denmark, 2015.

22. Otegui Carles, A. Los Estereotipos de Género En La Educación. Estereotipos de Género En La Vestimenta: La Reivindicación Del 4 de Noviembre. In $4^{\circ}$ Congreso Mundial de Educación EDUCA; OBIPD: Barcelona, Spain, 2021; pp. 869-882. 
23. ONU Mujeres Guatemala. Profundicemos en Términos: Guía para Periodistas, Comunicadoras y Comunicadores. Available online: http:/ / onu.org.gt/wp-content/uploads/2017/10/Guia-lenguaje-no-sexista_onumujeres.pdf (accessed on 9 September 2021).

24. Liberati, A.; Altman, D.G.; Tetzlaff, J.; Mulrow, C.; Gøtzsche, P.C.; Ioannidis, J.P.A.; Clarke, M.; Devereaux, P.J.; Kleijnen, J.; Moher, D. The PRISMA Statement for Reporting Systematic Reviews and Meta-Analyses of Studies That Evaluate Health Care Interventions: Explanation and Elaboration. J. Clin. Epidemiol. 2009, 62, e1-e34. [CrossRef] [PubMed]

25. Page, M.J.; McKenzie, J.E.; Bossuyt, P.M.; Boutron, I.; Hoffmann, T.C.; Mulrow, C.D.; Shamseer, L.; Tetzlaff, J.M.; Akl, E.A.; Brennan, S.E.; et al. The PRISMA 2020 Statement: An Updated Guideline for Reporting Systematic Reviews. BMJ 2021, $372,71$. [CrossRef]

26. Benckendorff, P.; Zehrer, A. A network analysis of tourism research. Ann. Tour. Res. 2013, 43, 121-149. [CrossRef]

27. Koseoglu, M.A.; Rahimi, R.; Okumus, F.; Liu, J. Bibliometric studies in tourism. Ann. Tour. Res. 2016, 61, 180-198. [CrossRef]

28. Ying, T.; Xiao, H. Knowledge linkage a social network analysis of tourism dissertation subjects. J. Hosp. Tour. Res. 2012, 36, 450-477. [CrossRef]

29. Bardin, L. Análise de Conteúdo; Edições 70. 2000. Available online: https:/ / docplayer.com.br/48553626-Analise-de-conteudosao-paulo-edicoes-70-2004-229p-adriana-santos.html (accessed on 29 September 2021).

30. Molinos, D.N.; Mesquita, D.G.; Hoff, D.N. ZipfTool: Uma ferramenta bibliométrica para auxílio na pesquisa teórica. Rev. Inf. Teórica Apl. 2016, 23, 293-317. [CrossRef]

31. Bosman, J.; Mourik, I.V.; Rasch, M.; Sieverts, E.; Verhoeff, H. Scopus Reviewed and Compared: The Coverage and Functionality of the Citation Database Scopus, Including Comparisons with Web of Science and Google Scholar; Utrecht University Library: Utrecht, The Netherlands, 2006.

32. Schreier, M. Qualitative Content Analysis in Practice; Sage Publications: New York, NY, USA, 2012.

33. Mudarra-Fernández, A.B.; Carrillo-Hidalgo, I.; Pulido-Fernández, J.I. Factors influencing tourist expenditure by tourism typologies: A systematic review. Anatolia 2018, 30, 18-34. [CrossRef] 